\title{
Liver Dysfunction
}

National Cancer Institute

\section{Source}

National Cancer Institute. Liver Dysfunction. NCI Thesaurus. Code C50634.

A finding that indicates abnormal liver function. 